\title{
Survival of frozen mouse embryos after rapid thawing from $-196^{\circ} \mathrm{C}$
}

\author{
D. G. Whittingham*, Maureen Wood †, J. Farrant $\ddagger$ H. Leeł and \\ J. A. Halsey* \\ ${ }^{*}$ M.R.C. Mammalian Development Unit, Wolfson House (University College London), \\ 4 Stephenson Way, London NW1 2HE; $†$ M.R.C. Laboratory Animals Centre, Woodmansterne \\ Road, Carshalton, Surrey SM5 4EF; and $\ddagger M . R . C$. Clinical Research Centre, Northwick \\ Park Hospital, Watford Road, Harrow, Middlesex HAl 3UJ, U.K.
}

\begin{abstract}
Summary. The effect of the rate of rewarming on the survival of 8 -cell mouse embryos and blastocysts was examined. The samples were slowly cooled $(0.3-$ $0.6^{\circ} \mathrm{C} / \mathrm{min}$ ) in $1.5 \mathrm{M}$-DMSO to temperatures between -10 and $-80^{\circ} \mathrm{C}$ before direct transfer to liquid nitrogen $\left(-196^{\circ} \mathrm{C}\right)$. Embryos survived rapid thawing $(275-$ $500^{\circ} \mathrm{C} / \mathrm{min}$ ) only when slow cooling was terminated at relatively high subzero temperatures $\left(-10\right.$ to $\left.-50^{\circ} \mathrm{C}\right)$. The highest levels of survival in vitro of rapidly thawed 8-cell embryos were obtained after transfer to $-196^{\circ} \mathrm{C}$ from -35 and $-40^{\circ} \mathrm{C}(72$ to $88 \%)$ and of rapidly thawed blastocysts after transfer from -25 to $-50^{\circ} \mathrm{C}$ (69 to $74 \%$ ). By contrast, for embryos to survive slow thawing (8 to $\left.20^{\circ} \mathrm{C} / \mathrm{min}\right)$ slow cooling to lower subzero temperatures $\left(-60^{\circ} \mathrm{C}\right.$ and below) was required before transfer to $-196^{\circ} \mathrm{C}$. The results indicate that embryos transferred to $-196^{\circ} \mathrm{C}$ from high subzero temperatures contain sufficient intracellular ice to damage them during slow warming but to permit survival after rapid warming.

Survival of embryos after rapid dilution of DMSO at room temperature was similar to that after slow (stepwise) dilution at $0^{\circ} \mathrm{C}$. There was no difference between the viability of rapidly and slowly thawed embryos after transfer to pseudopregnant foster mothers. It is concluded that the behaviour of mammalian embryos subjected to the stresses of freezing and thawing is similar to that of other mammalian cells. A simpler and quicker method for the preservation of mouse embryos is described.
\end{abstract}

\section{Introduction}

The two most important factors which contributed to the first successful attempts to preserve mammalian embryos at low temperatures were the rates at which the embryos were cooled and rewarmed. Optimal survival of mouse embryos was achieved with relatively low rates of cooling $\left(0.2-0.8^{\circ} \mathrm{C} / \mathrm{min}\right)$ and rewarming $\left(4-25^{\circ} \mathrm{C} / \mathrm{min}\right)$ with dimethyl sulphoxide (DMSO) as the cryoprotective agent (Whittingham, Leibo \& Mazur, 1972; Wilmut, 1972). For 8-cell mouse embryos stored at $-196^{\circ} \mathrm{C}$, the critical ranges of temperature over which these low rates were necessary for optimal survival were from -4 to $-60^{\circ} \mathrm{C}$ during cooling and from -70 to $-20^{\circ} \mathrm{C}$ during rewarming (Leibo, Mazur \& Jackowski, 1974).

The sensitivity of different cell types to the rate of cooling is well documented (Rapatz \& Luyet, 1965; Mazur, Farrant, Leibo \& Chu, 1969; Leibo, Farrant, Mazur, Hanna \& Smith, 1970; Farrant, Knight \& Morris, 1972). During slow cooling cells shrink in response to the increasing concentrations of solutes as water freezes in the external medium. If cooling is too rapid the cells freeze internally; in mouse embryos this has been observed directly with a 
cryomicroscope (Leibo, 1977a). The injurious effects of intracellular ice may result either from direct action during its growth and recrystallisation on rewarming (Mazur, 1966) or from osmotic stresses imposed on the cells once the intracellular ice has melted (Farrant, 1977). It is now clear that some cell types can survive when a small quantity of intracellular ice is present provided that thawing is rapid and that the amount of intracellular ice formed during the cooling phase does not exceed a critical amount (Sherman, 1962; Farrant, Walter, Lee \& McGann, 1977).

Earlier studies with mouse embryos showed that a small percentage $(\sim 10 \%)$ of 8 -cell embryos (Whittingham et al., 1972) and blastocysts (Wilmut, 1972) can survive rapid thawing $\left(360-450^{\circ} \mathrm{C} / \mathrm{min}\right)$ when cooled at rates ranging between 1 and $10^{\circ} \mathrm{C} / \mathrm{min}$. Moreover, the first successful storage of blastocysts from the cow was obtained after slow cooling $\left(0 \cdot 22^{\circ} \mathrm{C} / \mathrm{min}\right)$ and rapid thawing $\left(360^{\circ} \mathrm{C} / \mathrm{min}\right)$ but again survival was low $(<10 \%)$ (Wilmut $\&$ Rowson, 1973). Therefore, it was concluded that rapid warming was detrimental to embryonic survival whatever the rate of cooling. However, it has been shown recently that sheep and cow embryos can survive rapid thawing $\left(360^{\circ} \mathrm{C} / \mathrm{min}\right)$ provided the slow cooling at $0.3^{\circ} \mathrm{C} / \mathrm{min}$ is terminated between -30 and $-45^{\circ} \mathrm{C}$ by direct transfer to liquid nitrogen (Willadsen, 1977; Willadsen, Polge \& Rowson, 1978; Polge \& Willadsen, 1978).

In this paper we (1) examine in detail the effects of rapid thawing on the in-vitro survival of 8-cell mouse embryos and blastocysts slowly cooled to temperatures between -10 and $-80^{\circ} \mathrm{C}$ before direct transfer into liquid nitrogen and (2) compare the survival of slowly and rapidly thawed embryos after transfer to pseudopregnant foster mothers. In addition, we studied the sensitivity of embryos to the rates and temperatures of removal of the cryoprotective agent after thawing.

\section{Materials and Methods}

Since this paper was compiled from the results of experiments conducted in separate laboratories, there are minor differences in the experimental design and procedures for each series of experiments, and these are described in detail below.

\section{Source and collection of embryos}

Embryos were obtained from (a) mature random-bred LACA and 129C3, $\mathrm{F}_{1}(129 / \mathrm{RrJ} \% \times$ $\mathrm{C} 3 \mathrm{H} / \mathrm{He}^{7}$ ) mice for the preliminary dilution study, (b) 6-8-week-old C57BL/6JLac (ob/ + or $+/+$ ), subsequently referred to as $\mathrm{BL} / 6$, for the first series of rapid thawing experiments, and (c) 3-4-week-old randombred MF1 (Olac, U.K.) mice for the second series of rapid thawing experiments. Intraperitoneal injections of 5-7.5 i.u. PMSG and 5-7.5 i.u. hCG were given 44$48 \mathrm{~h}$ apart. After the injection of hCG, the females were paired with males of a similar strain, unless otherwise stated, and inspected the next day for copulation plugs. The day that the copulation plug was found was designated Day 1 of pregnancy. Although the gonadotrophin treatment induced synchronous mating, superovulation was only obtained consistently in the randombred MF1 strain. Embryos at the 8-cell stage were flushed from the excised oviducts and early blastocysts from the uteri with a modified Dulbecco's phosphate-buffered medium (PBI: for details see Whittingham, 1974a) on Days 3 and 4 of pregnancy, respectively. At each collection, the embryos were pooled and washed twice with PBI medium $(2 \mathrm{ml} /$ wash) before transfer to freezing tubes.

\section{Freezing}

The freezing procedures were essentially the same as those described previously for mouse embryos (Whittingham et al., 1972; Whittingham 1974a). Between 10 and 28 embryos were transferred to each freezing tube $(10 \times 100 \mathrm{~mm}$ or $12 \times 100 \mathrm{~mm}$ glass test-tubes $)$ which 
contained either $0.1 \mathrm{ml}$ or $0.15 \mathrm{ml}$ of PBI medium. The 8 -cell embryos were cooled to $0^{\circ} \mathrm{C}$ by placing in an icebath and an equal volume of PBI medium and $3 \mathrm{M}$-dimethyl sulphoxide (DMSO) was added (final concentration of $1.5 \mathrm{M}$-DMSO). DMSO was added to the blastocysts in 3 equal increments, $5 \mathrm{~min}$ apart, at room temperature before transfer to an icebath at $0^{\circ} \mathrm{C}$. For the preliminary dilution study and the second series of rapid thawing experiments, the embryos were held after the addition of DMSO at $0^{\circ} \mathrm{C}$ for $15 \mathrm{~min}$ before transfer to a $-6^{\circ} \mathrm{C}$ bath. Ice formation was induced 2-3 min later by seeding each sample with ice crystals contained in the tip of a Pasteur pipette. After holding for a further $5 \mathrm{~min}$ at $-6^{\circ} \mathrm{C}$, the samples were transferred to a constantly stirred ethanol cooling vessel at $-6^{\circ} \mathrm{C}$. In the first series of rapid thawing experiments, embryos were equilibrated with DMSO at $0^{\circ} \mathrm{C}$ for $5 \mathrm{~min}$ before transfer to a bath at $-9^{\circ} \mathrm{C}$. Ice formation was induced 2 min later by sharply tapping each tube, and the samples were immediately transferred to a cooling vessel at $-6^{\circ} \mathrm{C}$ (for details see Morris \& Farrant, 1972). Cooling rates were calculated from the time taken to cool samples from -10 to $-60^{\circ} \mathrm{C}$, and the rates ranged between 0.27 and $0.57^{\circ} \mathrm{C} / \mathrm{min}$.

At various temperatures between -10 and $-80^{\circ} \mathrm{C}$ samples were removed from the cooling vessels and either thawed immediately or transferred directly into liquid nitrogen $\left(-196^{\circ} \mathrm{C}\right)$ where they were held for periods between $1 \mathrm{~h}$ and 100 days.

\section{Thawing}

Slowly thawed samples were either allowed to thaw on the bench in air at room temperature $\left(\sim 20^{\circ} \mathrm{C} / \mathrm{min}\right)$ or placed in an evacuated Dewar flask $\left(\sim 8^{\circ} \mathrm{C} / \mathrm{min}\right)$. Rapidly warmed samples were either placed in a $37^{\circ} \mathrm{C}$ water bath or vigorously agitated in a $40^{\circ} \mathrm{C}$ bath until all the ice had disappeared $\left(\sim 275^{\circ} \mathrm{C} / \mathrm{min}\right.$ or $\left.\sim 500^{\circ} \mathrm{C} / \mathrm{min}\right)$. Rates of thawing were calculated from the rate of the temperature change occurring between -60 and $-10^{\circ} \mathrm{C}$ for samples cooled to $-60^{\circ} \mathrm{C}$ and below and suitably modified for samples warmed from higher subzero temperatures.

\section{Dilution of DMSO}

Initially the thawed samples were diluted in one of two ways: (a) stepwise dilution at $0^{\circ} \mathrm{C}$ or room temperature by adding, at 1-min intervals, $0.2,0.2$ and $0.4 \mathrm{ml}$ or $0.3,0.3$ and $0.6 \mathrm{ml} \mathrm{PBI}$ medium depending upon the original sample volume $(0.2$ or $0.3 \mathrm{ml})$, or (b) the single addition of 0.8 or $1.0 \mathrm{ml}$ PBI medium (for sample volumes of 0.2 and $0.3 \mathrm{ml}$ respectively) at room temperature, i.e. $5 \mathrm{~min}$ after thawing. The contents of each tube were emptied into an embryological watchglass, the tubes were rinsed twice with $1 \mathrm{ml} \mathrm{PBI}$ medium and the embryos recovered. Of 3693 embryos treated, 3307 (89.5\%) were recovered and cultured.

\section{Survival assays}

In vitro. After recovery the embryos were washed twice with PBI medium ( $2 \mathrm{ml} / \mathrm{wash})$ and cultured in drops of a standard mouse embryo culture medium (No. 16, for details see Whittingham, 1971) overlaid with paraffin oil and incubated at $37^{\circ} \mathrm{C}$ in an atmosphere of $5 \% \mathrm{CO}_{2}$ in air (Biggers, Whitten \& Whittingham, 1971). Survival of frozen-thawed 8-cell embryos was defined as the proportion of recovered embryos developing into blastocysts after $24-48 \mathrm{~h}$ in culture. For frozen-thawed blastocysts, survival was defined as the proportion of recovered blastocysts which re-expanded and were morphologically normal in appearance after $24 \mathrm{~h}$ in vitro. In most instances, control groups of embryos were exposed to $1.5 \mathrm{M}$-DMSO at $0^{\circ} \mathrm{C}$, recovered without further cooling and cultured. Overall, $94.5 \%$ (154/163) of the control 8-cell embryos developed to the blastocyst stage, and $100 \%(50 / 50)$ of the control blastocysts continued to expand in vitro. 
In vivo. Frozen-thawed 8-cell embryos and blastocysts were cultured for $20-24 \mathrm{~h}$ and embryos which had developed normally in vitro were transferred to the uterine horns (6-8 embryos per horn) of females on Day 3 of pseudopregnancy. The recipients were mature $F_{1}$ hybrid females (C57BL $q \times \mathrm{CBA}^{\star}$ or $\mathrm{C} 57 \mathrm{BL} q \times \mathrm{A} 2 \mathrm{G} \delta^{7}$ ) that were naturally mated with sterile males (carrying the translocation T145 (Lyon \& Meredith, 1966)). All females were killed and examined between Days 14 and 17 of gestation and the numbers of normal live embryos and resorbing implantation sites (moles) were recorded. All recipient females (49) became pregnant with transferred embryos.

\section{Results}

\section{Dilution of DMSO}

In a preliminary study, the survival of frozen-thawed 8-cell mouse embryos was compared after initially diluting the DMSO from the thawed samples with PBI medium, either in a stepwise manner at 0 or $20^{\circ} \mathrm{C}$ (room temperature), or by the single rapid addition of PBI medium at $20^{\circ} \mathrm{C}$. Before dilution, the embryos were cooled slowly at 0.30 to $0.46^{\circ} \mathrm{C} / \mathrm{min}$ in $1.5 \mathrm{M}$-DMSO to between -70 and $-80^{\circ} \mathrm{C}$ and then transferred directly to liquid nitrogen where they were held for various times (1-23 days) before being rewarmed slowly at 4.8 to $5.9^{\circ} \mathrm{C} / \mathrm{min}$ to $0^{\circ} \mathrm{C}$ and $20^{\circ} \mathrm{C}$. The combined responses for each treatment are presented in Table 1 since there were no statistically significant differences between the proportions of recovered embryos developing to blastocysts after $48 \mathrm{~h}$ in vitro within each treatment ( $\chi^{2}$ analysis). Furthermore, although the overall response after the single addition of PBI at $20^{\circ} \mathrm{C}$ appeared higher $(61.6 \%)$ than those after the stepwise dilution at 0 and $20^{\circ} \mathrm{C}(49.0 \%$ and $56.3 \%$, respectively), the difference was not significant ( $\chi^{2}$ analysis). Comparisons of stepwise and rapid dilution of DMSO at $20^{\circ} \mathrm{C}$ were also made in the second series of transfer experiments, and again no significant differences were found. The results demonstate that the initial rapid dilution of DMSO upon thawing does not exert any additional deleterious effect on embryo survival. In addition, it has the technical advantage of being simpler to execute than the stepwise method of dilution that has been used previously (Whittingham et al., 1972).

Table 1. Survival of 8-cell mouse embryos frozen in $0.2 \mathrm{ml}$ medium with $1.5 \mathrm{M}$-DMSO at 0.3 to $0.46^{\circ} \mathrm{C} / \mathrm{min}$ to between -70 and $-80^{\circ} \mathrm{C}$ before transfer to liquid nitrogen and the DMSO initially diluted either slowly or rapidly after thawing at 4.8 to $5.9^{\circ} \mathrm{C} / \mathrm{min}$

\begin{tabular}{ccccc}
\hline \multicolumn{2}{c}{ Dilution } & & & \\
$\begin{array}{c}\text { Temperature } \\
{ }^{\circ} \mathrm{C}\end{array}$ & Method & $\begin{array}{c}\text { No. of embryos } \\
\text { recovered }\end{array}$ & $\begin{array}{c}\text { to blastocysts after } 48 \mathrm{~h} \\
\text { in culture }\end{array}$ & $\begin{array}{c}\% \\
\text { Survival }\end{array}$ \\
\hline 0 & Slow* & 100 & 49 & 49.0 \\
20 & Slow* & 96 & 54 & $56 \cdot 3$ \\
20 & Rapid $\dagger$ & 99 & 61 & 61.6 \\
\hline
\end{tabular}

Values are for 5 replicates of each treatment ( $4 \times 20$ and $1 \times 27$ embryos).

* Stepwise addition of $0.2,0.2$ and $0.4 \mathrm{ml} \mathrm{PBI}$ at 1 -min intervals.

+ Single addition of $0.8 \mathrm{ml}$ PBI.

\section{Thawing rate and transfer temperature to $-196^{\circ} \mathrm{C}$}

In the first series of experiments, 8-cell embryos were slowly cooled at $0.3^{\circ} \mathrm{C} / \mathrm{min}$ to various temperatures between -30 and $-60^{\circ} \mathrm{C}$, after which they were either thawed immediately or cooled rapidly to $-196^{\circ} \mathrm{C}$ by direct immersion in liquid nitrogen. The samples were either thawed slowly at $\sim 12^{\circ} \mathrm{C} / \mathrm{min}$ or rapidly at $\sim 275^{\circ} \mathrm{C} / \mathrm{min}$ and the DMSO initially diluted rapidly at $20^{\circ} \mathrm{C}$ 
as outlined above. The survival of embryos in vitro to the blastocyst stage is shown in Table 2 . The overall sample sizes were insufficient to make valid statistical analyses of the data. However, the results indicate that embryos survive rapid, but not slow, thawing when directly transferred to $-196^{\circ} \mathrm{C}$ from temperatures above $-40^{\circ} \mathrm{C}$. The highest survival rates were obtained with embryos transferred at -35 and $-40^{\circ} \mathrm{C}$ to liquid nitrogen and rewarmed rapidly $(71.9$ to $87.5 \%$ ). Survival of slowly thawed embryos transferred from -40 and $-60^{\circ} \mathrm{C}$ to $-196^{\circ} \mathrm{C}$ increased from $6.5 \%$ to $65 \%$ whereas the survival of similarly cooled embryos appeared to decrease after rapid thawing. When the embryos were thawed before transfer to liquid nitrogen the survival was similar after rapid and slow thawing from temperatures between -30 and $-40^{\circ} \mathrm{C}$. Below $-40^{\circ} \mathrm{C}$ survival after rapid thawing decreased markedly to $10 \%$ at $-60^{\circ} \mathrm{C}$, whereas slow thawing from these lower temperatures did not alter the survival rate.

Table 2. In-vitro survival of 8-cell mouse embryos frozen in $1.5 \mathrm{M}$-DMSO at $0.3^{\circ} \mathrm{C} / \mathrm{min}$ to various temperatures between -30 and $-60^{\circ} \mathrm{C}$ and thawed rapidly $\left(275^{\circ} \mathrm{C} / \mathrm{min}\right)$ or slowly $\left(12^{\circ} \mathrm{C} / \mathrm{min}\right)$ before or after transfer to liquid nitrogen $\left(-196^{\circ} \mathrm{C}\right)$

\begin{tabular}{|c|c|c|c|c|}
\hline \multirow{3}{*}{$\begin{array}{c}\text { Temperature to } \\
\text { which samples } \\
\text { slowly cooled } \\
\left({ }^{\circ} \mathrm{C}\right)\end{array}$} & \multicolumn{4}{|c|}{$\%$ Embryos developing to blastocysts after $48 \mathrm{~h}$ in vitro } \\
\hline & \multicolumn{2}{|c|}{ Thawed before transfer to $-196^{\circ} \mathrm{C}$} & \multicolumn{2}{|c|}{ Thawed after transfer to $-196^{\circ} \mathrm{C}$} \\
\hline & Slowly & Rapidly & Slowly & Rapidly \\
\hline-30 & $50 \cdot 0(3,36)$ & $47 \cdot 2(3,36)$ & $0 \quad(3,33)$ & $20 \cdot 0(3,30)$ \\
\hline-35 & $45 \cdot 5(3,33)$ & $55 \cdot 3(4,47)$ & $(4,43)$ & $76 \cdot 6(4,47)$ \\
\hline$-37 \cdot 5$ & $57 \cdot 1(2,21)$ & $80 \cdot 0(2,20)$ & $0 \quad(2,20)$ & $87 \cdot 5(3,32)$ \\
\hline-40 & $70 \cdot 3(3,37)$ & $61 \cdot 1(3,36)$ & $6 \cdot 5(3,31)$ & $71.9(3,32)$ \\
\hline-45 & $58 \cdot 3(1,12)$ & $38 \cdot 5(1,13)$ & $18 \cdot 2(1,11)$ & $30 \cdot 8(1,13)$ \\
\hline-60 & $54 \cdot 5(1,11)$ & $10 \cdot 0(1,10)$ & $65 \cdot 0(2,20)$ & $50 \cdot 0(1,10)$ \\
\hline
\end{tabular}

Values in parentheses represent the no. of samples thawed, total no. of embryos recovered after thawing.

In the second series of experiments, examining the effects of slow and rapid thawing on survival, embryos cooled in $1.5 \mathrm{M}$-DMSO at 0.30 to $0.57^{\circ} \mathrm{C} / \mathrm{min}$ were immersed directly from various temperatures between -10 and $-80^{\circ} \mathrm{C}$ into liquid nitrogen. After thawing at $\sim 20^{\circ} \mathrm{C} / \mathrm{min}$ or $\sim 500^{\circ} \mathrm{C} / \mathrm{min}$ the DMSO was diluted slowly (stepwise) or rapidly from the samples at $20^{\circ} \mathrm{C}$. The data for the survival of 8-cell embryos to the blastocyst stage after $48 \mathrm{~h}$ in vitro are shown in Text-fig. 1. The main effects of slow and rapid thawing were similar to those found in the previous experiments (Table 2), although in the former the range of transfer temperatures was more restricted. With rapid thawing a few embryos survived transfer from -10 to $-196^{\circ} \mathrm{C}(5 \cdot 1 \%)$; survival reached maximal levels at transfer temperatures of -35 and $-40^{\circ} \mathrm{C}$ $\left(71.7\right.$ and $78.7 \%$, respectively) and then declined at $-80^{\circ} \mathrm{C}(16.9 \%)$. The survival after transfer at $-30^{\circ} \mathrm{C}$ was higher than in the previous experiment $(65.4 \%$ versus $20.0 \%)$ and although this response differed from that of transfers made at $-40^{\circ} \mathrm{C}\left(\chi_{(1)}^{2}=4.714, P<0.05\right)$, it was similar to those of transfers at -35 and $-50^{\circ} \mathrm{C}$. The faster thawing rate in these experiments $\left(\sim 500^{\circ} \mathrm{C} / \mathrm{min}\right.$ versus $\sim 275^{\circ} \mathrm{C} / \mathrm{min}$ ) might be responsible for the increase in survival of embryos transferred at $-30^{\circ} \mathrm{C}$ and also for the relatively high survivals obtained from direct transfers from -20 and $-25^{\circ} \mathrm{C}$ to $-196^{\circ} \mathrm{C}(44.4 \%$ and $46.4 \%$, respectively). Comparing the two survival curves after slow and rapid thawing, major changes òccur in survival when embryos are transferred below $-40^{\circ} \mathrm{C}$ to $-196^{\circ} \mathrm{C}$; after rapid cooling from $-50^{\circ} \mathrm{C}$ survival is similar for slow and rapidly thawed embryos $\left(50.7 \%\right.$ and $61.7 \%$, respectively, $\chi^{2}$ not significant), but at $-80^{\circ} \mathrm{C}$ survival of slowly thawed embryos has increased to $80.6 \%$ and that of rapidly thawed embryos has decreased to $16.9 \%$. 


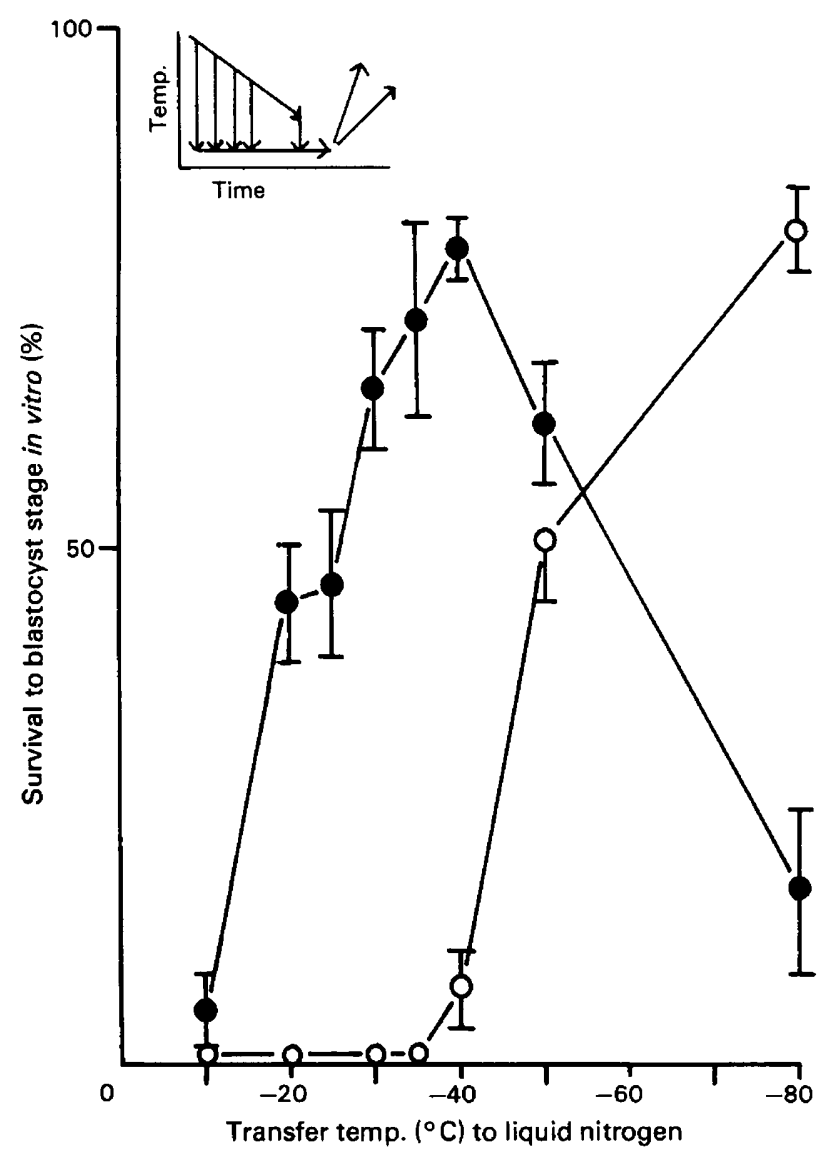

Text-fig. 1. Survival of 8-cell embryos to blastocyst stage in vitro after slow cooling in $1.5 \mathrm{M}$ DMSO at 0.30 to $0.57^{\circ} \mathrm{C} / \mathrm{min}$ to various temperatures between -10 and $-80^{\circ} \mathrm{C}$ before rapid cooling to $-196^{\circ} \mathrm{C}$ by direct immersion in liquid nitrogen and recovered after slow (O, $\sim 20^{\circ} \mathrm{C} / \mathrm{min}$ ) or rapid $\left(\mathrm{O}, \sim 500^{\circ} \mathrm{C} / \mathrm{min}\right.$ ) thawing from $-196^{\circ} \mathrm{C}$ (as indicated in the inset diagram). Values are mean \pm s.e.m. The number of replicate samples and the total number of embryos recovered after thawing (in parentheses) for each curve, starting with samples transferred at $-10^{\circ} \mathrm{C}$, were $2(38), 2(35), 3(55), 3(53), 4(68), 4(71)$ and 4 (72) for slow thawing (0); and 5 (78), 7 (108), 6 (84), 7 (107), 5 (99), 7 (108), 7 (107) and $6(89)$ for rapid thawing (O).

The survival of rapidly thawed blastocysts $\left(\sim 500^{\circ} \mathrm{C} / \mathrm{min}\right)$ was similar to that of 8-cell embryos after slow cooling and transfer to liquid nitrogen over the same temperature range (Text-fig. 2). However, blastocyst survival after transfer from $-25^{\circ} \mathrm{C}$ to $-196^{\circ} \mathrm{C}$ did differ significantly from similarly treated 8 -cell embryos $\left(73.9 \%\right.$ versus $46.4 \%, \chi_{(1)}^{2}=12.92, P<$ 0.001 ). Also, maximal responses occurred over a wider range of transfer temperatures ( -25 to $-50^{\circ} \mathrm{C}$ ) when compared with 8-cell embryos $\left(-35\right.$ to $\left.-40^{\circ} \mathrm{C}\right)$.

\section{Development of frozen-thawed embryos in vivo}

The developmental potential of rapidly thawed 8-cell embryos and blastocysts was assessed after transfer to pseudopregnant recipients. Embryos of each stage which survived direct immersion in liquid nitrogen from temperatures between -20 and $-50^{\circ} \mathrm{C}$ and culture for $24 \mathrm{~h}$ were pooled before transfer. The majority of rapidly thawed 8-cell embryos were transferred to 


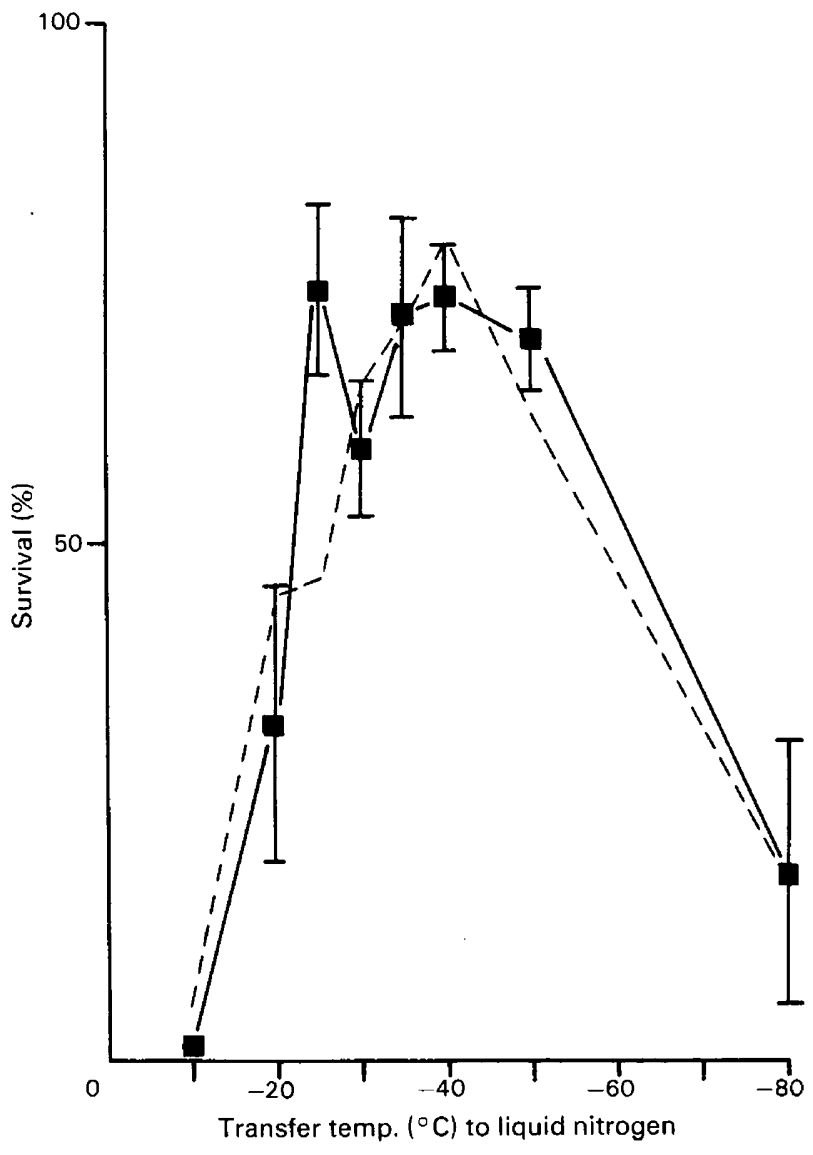

Text-fig. 2. Survival of blastocysts frozen under identical conditions to those outlined for 8-cell embryos in Text-fig. 1 and warmed rapidly $\left(\sim 500^{\circ} \mathrm{C} / \mathrm{min}\right)$ from $-196^{\circ} \mathrm{C}$. Survival was assessed by the number of thawed blastocysts which re-expanded and appeared morphologically normal after $24 \mathrm{~h}$ in vitro. Values are mean \pm s.e.m. The number of replicate samples and the total number of blastocysts recovered after thawing (in parentheses), starting with samples transferred at $-10^{\circ} \mathrm{C}$, were $5(88), 5(87), 5(92), 5(92), 5(94), 5(90), 3(55)$ and $3(56)$. The dashed line (---) represents the data for the survival of rapidly thawed 8-cell embryos (see Text-fig. 1) for comparison.

both uterine horns of a recipient female, but to compare the development of rapidly thawed 8-cell embryos and blastocysts the two stages were transferred to separate horns within the same recipient female. On examination at Day 14 or 15 of gestation, the proportions of implantation sites and live fetuses were similar for rapidly thawed embryos of both developmental stages (Table 3). The survival data for 8-cell embryos transferred solely to one recipient or in combination with blastocysts was similar, and therefore the combined data for 8-cell survival are presented in Table 3.

A second set of embryo transfer experiments was carried out to compare the survival in vivo of 8-cell embryos after slow or rapid thawing. In order to examine development under similar conditions, i.e. within the same uterine horn of a recipient female, two types of embryos that were distinguishable by eye pigment from Day 12 of gestation (MF1\% $\times$ MF1 $\delta^{\circ}$, nonpigmented; MF $1 \% \times \mathrm{C}^{\circ} 7 \mathrm{Bl}^{\gamma} \delta^{2}$, pigmented) were thawed at $\sim 500^{\circ} \mathrm{C} / \mathrm{min}$ after direct transfer from $-40^{\circ} \mathrm{C}$ to $-196^{\circ} \mathrm{C}$, or at $\sim 20^{\circ} \mathrm{C} / \mathrm{min}$ after direct transfer from $-80^{\circ} \mathrm{C}$ to $-196^{\circ} \mathrm{C}$. After culture for $24 \mathrm{~h}$, 
Table 3. In-vivo development of 8-cell mouse embryos and blastocysts, previously cooled slowly $\left(\sim 0.4^{\circ} \mathrm{C} / \mathrm{min}\right)$ to temperatures between -20 and $-50^{\circ} \mathrm{C}$ before transfer to $-196^{\circ} \mathrm{C}$, thawed rapidly $\left(\sim 500^{\circ} \mathrm{C} / \mathrm{min}\right)$ and transferred after $24 \mathrm{~h}$ in vitro to the uteri of recipients on Day 3 of pseudopregnancy

\begin{tabular}{lccc}
\hline & & \multicolumn{2}{c}{$\begin{array}{c}\text { Examination on Day } 14 \text { or } 15 \text { of } \\
\text { gestation }\end{array}$} \\
\cline { 3 - 4 } $\begin{array}{c}\text { Stage } \\
\text { frozen }\end{array}$ & $\begin{array}{c}\text { No. of embryos } \\
\text { transferred }\end{array}$ & $\begin{array}{c}\text { No. of implantation } \\
\text { sites (\%) }\end{array}$ & $\begin{array}{c}\text { No. of live } \\
\text { fetuses }(\%)\end{array}$ \\
\hline 8-cell & 251 & $189(75 \cdot 3)$ & $160(63 \cdot 7)$ \\
Blastocyst & 57 & $44(77 \cdot 2)$ & $36(63 \cdot 2)$ \\
\hline
\end{tabular}

3 embryos (MF $1 \times M F 1)$ thawed rapidly and 3 embryos (MF $1 \times$ C57BL) thawed slowly were transferred to one uterine horn and the reciprocal combination of embryos to the other horn of each pseudopregnant recipient. The data presented in Table 4 represent the combined results of 4 experiments. A total of 294 embryos were transferred to 25 pseudopregnant females, all of which were pregnant when examined between 15 and 17 days of gestation. A total of 244 $(83.0 \%)$ embryos implanted and 205 of these were normal live fetuses $(69.7 \%)$. The proportions of embryos implanting and developing to live fetuses within uterine horns receiving rapidly thawed MF $1 \times$ MF 1 embryos and slowly thawed MF1 $\times$ C57BL embryos $(128 / 150,85.3 \%$ implantations; $105 / 150,70.0 \%$ live fetuses) were similar to those in uterine horns receiving the reciprocal combination of treatments $(116 / 144,80.6 \%$ implantations; $100 / 144,69.4 \%$ live fetuses). The proportions of live fetuses that developed within each treatment were also similar and not statistically different by $\chi^{2}$ analysis. The results demonstrate that there is no difference between the post-implantation survival of frozen 8-cell embryos thawed rapidly after transfer

Table 4. Postimplantation survival of slowly and rapidly thawed 8-cell mouse embryos compared by transferring equal numbers of genetically marked* embryos ( 3 slowly +3 rapidly thawed embryos) to each uterine horn of recipients on the 3 rd day of pseudopregnancy

\begin{tabular}{|c|c|c|c|c|}
\hline & \multicolumn{4}{|c|}{ Embryos transferred } \\
\hline & $\mathrm{MF} 1 \times \mathrm{MF} 1$ & $\mathrm{MF} 1 \times \mathrm{C} 57 \mathrm{BL}$ & $\mathrm{MF} 1 \times \mathrm{MF} 1$ & $\mathrm{MF} 1 \times \mathrm{C} 57 \mathrm{BL}$ \\
\hline $\begin{array}{l}\text { Temp. }\left({ }^{\circ} \mathrm{C}\right) \text { when transferred to } \\
-196^{\circ} \mathrm{C} \\
\text { Thawing rate }\left({ }^{\circ} \mathrm{C} / \mathrm{min}\right)\end{array}$ & $\begin{array}{r}-40 \\
\sim 500\end{array}$ & $\begin{array}{r}-80 \\
\sim 20\end{array}$ & $\begin{array}{l}-80 \\
\sim 20\end{array}$ & $\begin{array}{r}-40 \\
\sim 500\end{array}$ \\
\hline No. of embryos frozen and thawed & 180 & 114 & 160 & 145 \\
\hline $\begin{array}{l}\text { No. of morulae and early } \\
\text { blastocysts after } 24 \text { h in vitro } \\
(\%)\end{array}$ & $\begin{array}{c}128 \\
(71 \cdot 1)\end{array}$ & $\begin{array}{c}75 \\
(65.8)\end{array}$ & $\begin{array}{c}109 \\
(68.1)\end{array}$ & $\begin{array}{c}80 \\
(55.2)\end{array}$ \\
\hline $\begin{array}{l}\text { No. of embryos transferred to } \\
\text { recipients } \dagger\end{array}$ & 75 & 75 & 72 & 72 \\
\hline $\begin{array}{l}\text { No. of live fetuses at } 15-17 \text { days } \\
\text { days gestation (\%) }\end{array}$ & $\begin{array}{c}57 \\
(76 \cdot 0)\end{array}$ & $\begin{array}{c}48 \\
(64 \cdot 0)\end{array}$ & $\begin{array}{c}53 \\
(73 \cdot 6)\end{array}$ & $\begin{array}{c}47 \\
(65 \cdot 3)\end{array}$ \\
\hline $\begin{array}{l}\text { Estimated overall survival } \\
\text { expressed as \% of no. of } \\
\text { embryos frozen and thawed }\end{array}$ & $54 \cdot 0$ & $42 \cdot 1$ & $50 \cdot 1$ & $36 \cdot 0$ \\
\hline
\end{tabular}

*MF1 $\times$ MF1 and MF1 $\times$ C57BL fetuses have non-pigmented and pigmented eyes, respectively, from 12 days of gestation.

$\dagger$ All 25 recipients became pregnant with transferred embryos: 24 recipients received both genetic combinations, 1 recipient received combination MF $1 \times$ C57BL into 1 uterine horn only. 
from $-40^{\circ} \mathrm{C}$ to $-196^{\circ} \mathrm{C}$ and those thawed slowly after transfer from $-80^{\circ} \mathrm{C}$ to $-196^{\circ} \mathrm{C}$. It was not possible to determine the exact percentage of embryos surviving to live fetuses from the total number originally frozen and thawed in each group because not all of the embryos surviving in vitro were transferred to recipients as there were insufficient numbers of foster mothers or combinations of embryos from the different treatments at the times of transfer. When estimates were made of the overall survival in each group (Table 4) from the proportions surviving in vitro and after transfer, slowly and rapidly thawed MF $1 \times M F 1$ embryos survived significantly better than slowly and rapidly thawed MF $1 \times$ C57BL embryos. This is due to the poorer survival of MF1 1 C57BL embryos after freezing and thawing and may reflect variations in the sensitivity of embryos of differing genotypes to freezing and thawing.

\section{Discussion}

In contrast to previous findings (Whittingham et al., 1972; Wilmut, 1972; Leibo et al., 1974), we have shown that 8-cell mouse embryos and blastocysts frozen with $1.5 \mathrm{M}$-DMSO survive rapid thawing, but only when slow cooling is changed to rapid cooling at relatively high subzero temperatures $\left(-10\right.$ to $\left.-50^{\circ} \mathrm{C}\right)$. After rapid thawing, survival reaches maximal levels when slowly cooled embryos are transferred from -35 and $-40^{\circ} \mathrm{C}$ to liquid nitrogen. To obtain similar survival after slow thawing, the slow cooling of embryos has to be continued to $-60^{\circ} \mathrm{C}$ or below before transfer to $-196^{\circ} \mathrm{C}$ (see Text-fig. 1, and Leibo et al., 1974). These results agree with observations on the survival in vitro of rapidly thawed sheep and cattle embryos (Willadsen, 1977; Willadsen et al., 1978; Polge \& Willadsen, 1978). Furthermore, the present data demonstrate for the first time that, under appropriate conditions of freezing, the survival of rapidly and slowly thawed mammalian embryos is similar after transfer to pseudopregnant recipients. The validity of this comparison was enhanced by comparing the survival of slowly and rapidly thawed embryos, identified by a genetic marker (eye pigment), within the same uterine horn of each pseudopregnant recipient.

In previous work, DMSO has been diluted from the embryos after thawing by a slow stepwise procedure, at $0^{\circ} \mathrm{C}$ (mouse: Whittingham et al., 1972; Whittingham, 1974a; Maurer, Bank \& Staples, 1977; rat: Whittingham, 1975), $20^{\circ} \mathrm{C}$ (mouse: Wilmut, 1972; cow: Wilmut \& Rowson, 1973; sheep: Willadsen, Polge, Rowson \& Moor, 1976), or $37^{\circ} \mathrm{C}$ (mouse blastocysts: Whittingham, 1974b; rabbit: Bank \& Maurer, 1974; Whittingham \& Adams, 1976), in order to reduce the osmotic stress during its removal. However, in several other cell systems abrupt osmotic stresses can be tolerated when the temperature of dilution is room temperature or above (Woolgar \& Morris, 1973; Thorpe, Knight \& Farrant, 1976). This is also true for 8-cell mouse embryos and blastocysts, since survival after rapid dilution of the DMSO at $20^{\circ} \mathrm{C}$ is similar to that after slow dilution at $0^{\circ} \mathrm{C}$ or $20^{\circ} \mathrm{C}$.

Two aspects of this study warrant further consideration. Firstly, events during freezing alter the sensitivity of the embryo to the rate of thawing. When mouse embryos are slowly cooled $\left(<1^{\circ} \mathrm{C} / \mathrm{min}\right)$ to temperatures below $-60^{\circ} \mathrm{C}$ in the presence of $1 \mathrm{M}$-DMSO, they shrink in response to the increasing concentration of extracellular electrolytes as water freezes in the external medium and apparently no intracellular ice forms (Leibo, 1977a, b). It is easy to explain the good recovery observed after slow thawing under these conditions, since there is no risk of the recrystallisation of intracellular ice. The poor survival after rapid thawing of these grossly shrunken embryos (without intracellular ice) is much harder to explain. Possibly slow rehydration is necessary for re-assembly of the subcellular structures in the embryo, but there is no evidence for this at present. The cryoprotectant may also play a role in maintaining the integrity of the slowly cooled embryos during rapid warming for when the concentration of DMSO is increased from 1.0 to $1.5 \mathrm{M}$, sheep embryos cooled at 0.3 and $1.0^{\circ} \mathrm{C} / \mathrm{min}$ survive rapid warming at $\sim 360^{\circ} \mathrm{C} / \mathrm{min}$ (Willadsen, 1977). 
If mouse embryos are cooled at rates exceeding $5^{\circ} \mathrm{C} / \mathrm{min}$ the nucleation of intracellular ice always occurs between -40 and $-50^{\circ} \mathrm{C}$ (Leibo, 1977a, b). A few mouse embryos have survived cooling at rates between 5 and $10^{\circ} \mathrm{C} / \mathrm{min}$ when rapidly warmed at $450^{\circ} \mathrm{C} / \mathrm{min}$ (Whittingham et al., 1972), thus suggesting that embryos can survive after intracellular ice has formed as previously demonstrated in other cell systems (Sherman, 1962; Farrant et al., 1977). Generally, cells containing too much intracellular ice are extremely sensitive to injury; the temperature at which injury occurs during rewarming varies with the system (Farrant et al., 1977; Mazur, 1977). The critical factor that determines injury is probably the amount of intracellular ice formed in relation to the rate of thawing (Farrant, 1977). It is likely that above a certain amount of intracellular ice no increase in the rate of rewarming will allow any survival.

The present results indicate that embryos plunged into liquid nitrogen after slow cooling to $-40^{\circ} \mathrm{C}$ contain enough intracellular ice at $-196^{\circ} \mathrm{C}$ to damage them during slow thawing (8$\left.20^{\circ} \mathrm{C} / \mathrm{min}\right)$ since rapid thawing $\left(275-500^{\circ} \mathrm{C} / \mathrm{min}\right)$ allows good survival. The amount of intracellular ice formed after slow cooling to $-40^{\circ} \mathrm{C}$ and transfer to $-196^{\circ} \mathrm{C}$ must be very small (see observations of Leibo, $1977 \mathrm{a}, \mathrm{b}$ ) but still sufficient to protect the embryos against rapid thawing injury. The intracellular ice may prevent osmotic damage during rapid warming by arresting the movement of water across the cell membranes (Farrant, 1977) or by limiting the exposure time to large fluctuations in solute concentrations. Obviously, many of these aspects await further investigation. Nevertheless, it may be concluded that the behaviour of mammalian embryos at low temperatures is not unique, as originally suggested (Whittingham et al., 1972), but similar to that of many other types of cells.

The second important aspect of this study is that rapid thawing and rapid dilution of the DMSO allow a useful simplification of the preservation procedure of mouse 8-cell embryos and blastocysts. The essential steps of this modified method are therefore as follows: (1) the incorporation of DMSO $(1.5 \mathrm{M})$ for 5 to $15 \mathrm{~min}$ at $0^{\circ} \mathrm{C}$; (2) nucleation of ice by sharply tapping each sample, 2-3 min after transfer to a $-9^{\circ} \mathrm{C}$ bath: (3) immediate transfer of samples to a cooling vessel at $-6^{\circ} \mathrm{C}$ and slow cooling $\left(0 \cdot 3-0 \cdot 6^{\circ} \mathrm{C} / \mathrm{min}\right)$ to $-40^{\circ} \mathrm{C}$; (4) at $-40^{\circ} \mathrm{C}$ the direct transfer of samples into liquid nitrogen for storage; (5) rapid thawing in a $37-40^{\circ} \mathrm{C}$ water bath until all the ice has disappeared: (6) after $5 \mathrm{~min}$ at room temperature, rapid dilution (5-fold) of the DMSO, followed by recovery and culture of embryos.

In conclusion, the behaviour of mouse embryos during freezing and thawing is comparable to that of other types of mammalian cells. The advantage of being able to transfer embryos from $-40^{\circ} \mathrm{C}$ to liquid nitrogen and subsequently thaw them rapidly, makes the technique quicker and more acceptable in practice.

\section{References}

Bank, H. \& Maurer, R.R. (1974) Survival of frozen rabbit embryos. Expl. Cell Res. 89, 188-196.

Biggers, J.D., Whitten, W.K. \& Whittingham, D.G. (1971) The culture of mouse embryos in vitro. In Methods in Mammalian Embryology, pp. 86-116. Ed. J. C. Daniel, Jr. W. H. Freeman \& Co., San Francisco.

Farrant, J. (1977) Water transport and cell survival in cryobiological procedures. Phil. Trans. Roy. Soc. Lond. B 278, 191-205.

Farrant, J., Knight, S.C. \& Morris, G.J. (1972) Use of different cooling rates during freezing to separate populations of human peripheral blood lymphocytes. Cryobiology 9, 516-525.

Farrant, J., Walter, C.A., Lee, H. \& McGann, L.E. (1977) Use of two-step cooling procedures to examine factors influencing cell survival following freezing and thawing. Cryobiology 14, 273-286.

Leibo, S.P. (1977a) Fundamental cryobiology of mouse ova and embryos. In The Freezing of Mammalian Embryos (Ciba Fndn Symp. No. 52 (new series)), pp. 69-92. Eds K. Elliott \& J. Whelan. Elsevier/North Holland, Amsterdam.

Leibo, S.P. (1977b) Preservation of mammalian cells and embryos by freezing. In Cryoimmunologie, pp. 311334. Eds D. Simatos, D.M. Strong \& J.-M. Turc. INSERM, Paris.

Leibo, S.P., Farrant, J., Mazur, P., Hanna, M.G. Jr. \& Smith, L.H. (1970) Effects of freezing on marrow stem cell suspensions: interactions of cooling and warming rates in the presence of PVP, sucrose, or glycerol. Cryobiology 6, 315-332. 
Leibo, S.P., Mazur, P. \& Jackowski, S.C. (1974) Factors affecting survival of mouse embryos during freezing and thawing. Expl Cell Res. 89, 79-88.

Lyon, M.F. \& Meredith, R. (1966) Autosomal translocations causing male sterility and variable aneuploidy in the mouse. Cytogenetics 5, 335-354.

Maurer, R.R., Bank, H. \& Staples, R.E. (1977) Pre and post natal development of mouse embryos after storage for different periods at cryogenic temperature. Biol. Reprod. 16, 139-146.

Mazur, P. (1966) Physical and chemical basis of injury in single-celled micro-organisms subjected to freezing and thawing. In Cryobiology, pp. 214-310. Ed. H. T. Meryman. Academic Press, New York.

Mazur, P. (1977) The role of intracellular freezing in the death of cells cooled at supraoptimal rates. Cryobiology 14, 251-272.

Mazur, P., Farrant, J., Leibo, S.P. \& Chu, E.H.Y. (1969) Survival of hamster tissue culture cells after freezing and thawing. Cryobiology 6, 1-9.

Morris, G.J. \& Farrant, J. (1972) Interactions of cooling rate and protective additive on the survival of washed human erythrocytes frozen to $-196^{\circ} \mathrm{C}$. Cryobiology 9, 173-181.

Polge, C. \& Willadsen, S.M. (1978) Freezing eggs and embryos of farm animals. Cryobiology 15, 370-373.

Rapatz, G. \& Luyet, B. (1965) Effects of cooling rates on the preservation of erythrocytes in frozen blood containing various protective agents. Biodynamica 9 , $333-350$.

Sherman, J.K. (1962) Survival of higher animal cells after the formation and dissolution of intracellular ice. Anat. Rec. 144, 171-189.

Thorpe, P.E., Knight, S.C. \& Farrant, J. (1976) Optimal conditions for the preservation of mouse lymph node cells in liquid nitrogen using cooling rate techniques. Cryobiology 13, 126-133.

Whittingham, D.G. (1971) Culture of mouse ova. $J$. Reprod. Fert., Suppl. 14, 7-21.
Whittingham, D.G. (1974a) Embryo banks in the future of developmental genetics. Genetics, Suppl. 78, 395402.

Whittingham, D.G. (1974b) The viability of frozenthawed mouse blastocysts. J. Reprod. Fert. 37, 159162.

Whittingham, D.G. (1975) Survival of rat embryos after freezing and thawing. J. Reprod. Fert. 43, 575-578.

Whittingham, D.G. \& Adams, C.E. (1976) Low temperature preservation of rabbit embryos. $J$. Reprod. Fert. 47, 269-274.

Whittingham, D.G., Leibo, S.P. \& Mazur, P. (1972) Survival of mouse embryos frozen to $-196^{\circ} \mathrm{C}$ and $-269^{\circ} \mathrm{C}$. Science N.Y. 178, 411-414.

Willadsen, S.M. (1977) Factors affecting the survival of sheep embryos during deep-freezing and thawing. In Freezing of Mammalian Embryos (Ciba Fndn Symp. No. 52 (new series)), pp. 175-189. Eds K. Elliott \& J. Whelan. Elsevier/North Holland, Amsterdam.

Willadsen, S.M., Polge, C., Rowson, L.E.A. \& Moor, R.M. (1976) Deep freezing of sheep embryos. $J$. Reprod. Fert. 46, 151-154.

Willadsen, S.M., Polge, C. \& Rowson, L.E.A. (1978) In vitro storage of cattle embryos. In Control of Reproduction in the Cow. Ed. J. Sreenan. European Economic Community, Luxembourg.

Wilmut, I. (1972) The effect of cooling rate, warming rate, cryoprotective agent and stage of development on survival of mouse embryos during freezing and thawing. Life Sciences 11, 1071-1079.

Wilmut, I. \& Rowson, L.E.A. (1973) Experiments on the low temperature preservation of cow embryos. Vet. Rec. 92, 686-690.

Woolgar, A.E. \& Morris, G.J. (1973) Some combined effects of hypertonic solutions and changes in temperature on posthypertonic haemolysis of human red blood cells. Cryobiology 10, 82-87.

Received 2 June 1978 